\title{
ANTISTREPTOLYSIN TITERS IN CASES OF FILARIASIS WITH RECURRENT LYMPHANGITIS AMONG MILITARY PERSONNEL
}

\author{
BY HARRY M. ROSE, JAMES T. CULBERTSON, AND MIRIAM OLMSTEAD LIPMAN \\ (From the Departments of Medicine and Bacteriology, Columbia University College of \\ Physicians and Surgeons, New York City)
}

(Received for publication December 4, 1944)

Since the outbreak of the war, thousands of military personnel have been stationed in islands of the South Pacific where a non-periodic type of Bancroftian filariasis is prevalent among the native populations, and large numbers of the troops, who have been intensively exposed to the bites of infected mosquitoes, have developed clinical manifestations of filariasis. The pattern of the disease in these men is similar to that described many years ago (1) in Europeans, a few months after their arrival in these same island groups, and consists primarily of a lymphadenitis and remittent lymphangitis, sometimes associated with constitutional symptoms of low-grade fever, chills, malaise, and nausea. The natives are well acquainted with this syndrome and call it "mumu."

The chief manifestations of "mumu," as seen among the troops, are lymphadenopathy of the axillary, inguinal, and epitrochlear nodes, with recurrent attacks of a retrograde or centrifugal lymphangitis, and the appearance of evanescent red, swollen, pruritic areas on the affected trunk or extremities $(2,3)$. The spermatic cord and scrotal contents are frequently affected, the commonest lesion being a funiculitis, with or without epididymitis, orchitis, or hydrocele (4). In the majority of cases, a definitive diagnosis of filariasis cannot be made, since microfilariae have thus far been found but rarely in the blood $(3,5)$; but the adult parasites have been recovered from involved lymph nodes in a number of patients (6, $7)$, and skin tests with filarial antigens have yielded positive results in about 85 per cent of the men with clinical evidence of the disease $(2,3$, 6,8 ).

The mechanism which excites the attacks of lymphangitis and fugitive swellings in these cases is of great interest. The aforementioned observers are in general agreement that the chief factor is a sensitization of the host to antigenic sub- stances elaborated by the adult parasites, and that the symptoms are the result of an immune or allergic type of reaction. This opinion is supported by the high incidence of positive skin tests, precipitin tests, and complement fixation reactions with filarial antigens among supposedly infected troops $(2,3,6,8)$, indicating that the majority have developed antibodies to the parasite; by the microscopic appearance of the tissue changes in biopsy specimens $(6,7)$; and by the fact that the local reactions occurring spontaneously in these naturally infected individuals may be reproduced in many of them following the intradermal inoculation of filarial antigens (2).

Another possible mechanism for the recurrent lymphangitis is secondary bacterial infection, since it is well-known from earlier work (9) that lymph stasis and lymph edema predispose to bacterial invasion, particularly with hemolytic streptococci. Furthermore, the so-called "tropical lymphangitis" of the Caribbean area, which clinically resembles the lymphangitis of "mumu" in some respects, has been definitely shown by bacteriological and serological procedures frequently to be initiated by streptococcal infections (10).

The infectious etiology of the lymphangitis seen in the cases of filariasis among military personnel has been investigated, using ordinary bacteriological procedures, and thus far cultures have failed to reveal hemolytic streptococci $(6,7)$. Cultural methods alone may, however, be inadequate, as was clearly demonstrated in cases of tropical lymphangitis (11), in which it was found to be difficult to isolate streptococci at the time of the attacks. It was shown, nevertheless, that the attacks were engendered by a streptococcal infection, since the majority of these cases subsequently showed an immune response characterized by an augmented titer of antistreptolysin "O" in the blood. 
The present report deals with an investigation of antistreptolysin titers in the blood of soldiers suffering from recurrent lymphangitis associated with filariasis. The study was undertaken to obtain additional evidence for or against streptococcal infections as a factor in producing the symptoms exhibited by these men.

\section{CLINICAL MATERIAL AND GENERAL PROCEDURES}

The clinical material consisted of 45 cases of suspected filariasis among military personnel recently returned from the South Pacific area, most of whom were observed by the authors at the Halloran General Hospital, Staten Island, New York. ${ }^{1}$ The remaining cases were seen at the Harmon General Hospital, Longview, Texas, by Colonel Alexander Marble and Captain A. A. Goodman, through whose interest and cooperation the clinical data and blood specimens were obtained.

All of the cases gave a history of one or more attacks of lymphangitis beginning 5 to 12 months after their initial exposure to infection, and the majority had regional lymphadenopathy at the time of examination. Many of the men had also noted transient painful swellings of the spermatic cord or scrotum, although only a few showed persistent enlargement of these structures. None of the cases gave a history of recent sore throats or other infections of the respiratory tract, nor of infections following injury to the body surface, but nearly all had had an attack of lymphangitis within 2 months preceding the date when blood was drawn for determination of the antistreptolysin titer.

Antistreptolysin titers were determined on single specimens of blood from each case; multiple specimens could not be obtained owing to the early transfer of the patients to other areas. The tests were performed by a modification of the method described by Coburn and Pauli (12), the final titers being reported as the highest dilutions of inactivated sera that would completely neutralize one standard unit of streptolysin (Todd).

Each patient was also skin-tested with filarial antigen prepared from Litomosoides carinii, as described in a previous publication (8). One tenth $\mathrm{ml}$. of this antigen, in a dilution of 1-200, was injected intracutaneously on the volar surface of one forearm, together with a similar amount of the diluent alone on the other forearm as a control. Positive reactions were characterized by the almost immediate appearance of an urticarial wheal at the site of the injected antigen, accompanied by surrounding erythema and usually by some local itching. The intensity of the reactions was estimated by measuring the longest perpendicular diameters of the wheals, 10 minutes after injection.

Blood smears to be examined for microfilariae were obtained by preparing thick films as for malarial parasites,

1 These cases were made available for study through the kindness of Colonel Ralph G. De Voe, Commanding Officer of Halloran General Hospital. de-hemoglobinizing in tap water, fixing in equal parts of ether and absolute alcohol, and staining with hematoxylin.

\section{RESULTS}

Antistreptolysin titers. The results of the tests for antistreptolysin titers are recorded in Table $I$.

TABLE I

Distribution of antistreptolysin titers in 45 cases of filariasis among military personnel

\begin{tabular}{c|c||c|c}
\hline \hline $\begin{array}{c}\text { Antistreptolysin } \\
\text { titer }\end{array}$ & $\begin{array}{c}\text { Number of } \\
\text { cases }\end{array}$ & $\begin{array}{c}\text { Antistreptolysin } \\
\text { titer }\end{array}$ & $\begin{array}{c}\text { Number of } \\
\text { cases }\end{array}$ \\
\cline { 2 - 3 } 20 & 2 & 125 & 2 \\
33 & 4 & 142 & 7 \\
62 & 4 & 166 & 4 \\
71 & 4 & 200 & 3 \\
83 & 5 & 250 & 3 \\
100 & 2 & 333 & 3 \\
111 & 2 & & \\
\hline
\end{tabular}

It will be seen that the titers varied from 20 to 333 units per ml. of serum; but, of the 45 cases, only 6 were found to have titers of 250 or more, while the remaining 39 cases showed values of 200 or less. It is the opinion of most observers that the range of antistreptolysin titers which may be regarded as normal is variable; however, for single specimens, it is generally considered that a titer of 250 units or more is elevated, while a titer lower than this is within normal limits (13). According to these criteria, therefore, the great majority of the cases of filariasis failed to show serological evidence of an antecedent streptococcal infection.

It is of interest further to compare the antistreptolysin titers obtained in this group of 45 cases with those found by others (14) among 47 normal male medical students. The figures for the two groups are given in Table II and show an

TABLE II

Comparison of antistreptolysin titers in 45 cases of filariasis and 47 normal adult males

\begin{tabular}{ccc}
\hline \hline Antistreptolysin titers & $\begin{array}{c}45 \text { cases of } \\
\text { filariasis }\end{array}$ & $\begin{array}{c}47 \text { normal males } \\
\text { (Rantz, Kirby } \\
\text { and Jacobs) }\end{array}$ \\
\hline Titer 100 or less & 21 & 23 \\
Titer 101 to 166 & 15 & 18 \\
Titer 200 & 3 & 6 \\
Titer 250+ & 6 & 6 \\
\hline
\end{tabular}

extremely close correlation, which is evidence that the distribution of the antistreptolysin titers among the cases of filariasis is similar to that 
TABLE III

Antistreptolysin titers in a case of tropical lymphangitis initiated by a hemolytic streptococcal infection

\begin{tabular}{|c|c|c|c|c|c|c|c|}
\hline & \multicolumn{7}{|c|}{ Interval after attack of lymphangitis } \\
\hline & 2 weeks & 3 weeks & 4 weeks & 5 weeks & 8 weeks & 13 weeks & 23 weeks \\
\hline Antistreptolysin titer & 550 & 550 & 550 & 620 & 830 & 550 & 500 \\
\hline
\end{tabular}

which may be found in normal males of approximately the same age.

In Table III, serial determinations of the antistreptolysin titer in a patient from the Caribbean area who suffered a typical attack of "tropical lymphangitis" are recorded. It will be noted that the antistreptolysin titer, which was 550 units 2 weeks after the attack, was still elevated at the twenty-third week, when the tests were discontinued. The high titers in this case illustrate the type of response which led other workers (11) to the conclusion that most cases of tropical lymphangitis are engendered by an infection with hemolytic streptococci; they are in marked contrast to the normal titers encountered in nearly all of the cases in our present series.

Skin tests. The skin tests with filarial antigen prepared from $L$. carinii were positive in 38 of the 45 cases, an incidence of 84.5 per cent. These results are almost identical with those obtained (2, 6) in a large series of cases tested with Dirofilaria immitis antigen, and serve to indicate that the majority of the men had serological as well as clinical evidence of a filarial infection.

No correlation was observed between the size of the skin wheals and the levels of the antistreptolysin titers, as is shown in Table IV. However, it was noted that the men who had suffered most severely from recurrent lymphangitis were, in a number of instances, those who displayed the most marked cutaneous responses to filarial antigen.

Microfilariae in the blood. Microfilariae were detected in the blood of only one patient. This finding is in harmony with that of the other investigators who have studied recently acquired filariasis among our military personnel $(2,3,5$, $6)$.

\section{DISCUSSION}

Although a definitive diagnosis of filariasis was made in only one patient of the present series by the discovery of microfilariae in the peripheral blood, there is good indirect evidence that the great majority, if not all, of the men, were suffering from a filarial infection contracted during their residence in areas of the South Pacific where the disease is highly endemic. Their symptoms, particularly the lymphadenopathy and recurrent lymphangitis, strongly suggested such an infection, and it is especially significant, from the diagnostic standpoint, that a large proportion of the men had developed a demonstrable immunological reaction to an antigen prepared from a filarial worm which is closely related to Wuchereria bancrofti.

The antistreptolysin titers were within normal limits in nearly all of these cases, only 6 of the 45 showing titers which were high enough to suggest the possibility of a recent streptococcal infection. These findings are in contrast to those of Morales and Pomales among cases of so-called "tropical

TABLE IV

Comparison of intensity of cutaneous reactions to filarial antigen and level of antistreptolysin titers in 45 cases of filariasis

\begin{tabular}{|c|c|c|c|c|c|}
\hline Case & $\begin{array}{l}\text { Skin tests: } \\
\text { diameters } \\
\text { of wheals }\end{array}$ & $\begin{array}{l}\text { Antistrep- } \\
\text { tolysin } \\
\text { titers }\end{array}$ & Case & $\begin{array}{l}\text { Skin tests: } \\
\text { diameters } \\
\text { of wheals }\end{array}$ & $\begin{array}{l}\text { Antistrep- } \\
\text { tolysin } \\
\text { titers }\end{array}$ \\
\hline $\begin{array}{r}1 \\
2 \\
3 \\
4 \\
5 \\
6 \\
7 \\
8 \\
9 \\
10 \\
11 \\
12 \\
13 \\
14 \\
15 \\
16 \\
17 \\
18 \\
19 \\
20 \\
21 \\
22 \\
23\end{array}$ & $\begin{array}{r}c m . \\
1.1 \times 1.1 \\
1.2 \times 1.0 \\
1.2 \times 1.0 \\
1.2 \times 1.1 \\
1.2 \times 1.1 \\
1.3 \times 1.0 \\
1.3 \times 1.1 \\
1.4 \times 1.4 \\
1.5 \times 1.2 \\
1.5 \times 1.3 \\
1.5 \times 1.5 \\
1.7 \times 1.5 \\
1.7 \times 1.6 \\
1.7 \times 1.7 \\
1.7 \times 1.7 \\
1.8 \times 1.5 \\
1.8 \times 1.5 \\
1.8 \times 1.6 \\
1.8 \times 1.6 \\
1.8 \times 1.7 \\
1.8 \times 1.8 \\
1.9 \times 1.7 \\
1.9 \times 1.7\end{array}$ & $\begin{array}{r}71 \\
62 \\
83 \\
33 \\
200 \\
33 \\
142 \\
142 \\
166 \\
250 \\
33 \\
62 \\
125 \\
250 \\
142 \\
166 \\
142 \\
33 \\
142 \\
62 \\
100 \\
71 \\
142\end{array}$ & $\begin{array}{l}24 \\
25 \\
26 \\
27 \\
28 \\
29 \\
30 \\
31 \\
32 \\
33 \\
34 \\
35 \\
36 \\
37 \\
38 \\
39 \\
40 \\
41 \\
42 \\
43 \\
44 \\
45\end{array}$ & $\begin{array}{l}c \mathrm{~cm} . \\
1.9 \times 1.8 \\
2.0 \times 1.8 \\
2.0 \times 2.0 \\
2.1 \times 1.7 \\
2.1 \times 2.0 \\
2.2 \times 2.0 \\
2.2 \times 2.0 \\
2.2 \times 2.0 \\
2.4 \times 1.8 \\
2.4 \times 2.0 \\
2.5 \times 2.3 \\
2.5 \times 2.4 \\
2.6 \times 2.2 \\
3.3 \times 2.5 \\
\text { Positive } \\
\text { Negative } \\
\text { Negative } \\
\text { Negative } \\
\text { Negative } \\
\text { Negative } \\
\text { Negative } \\
\text { Negative }\end{array}$ & $\begin{array}{r}100 \\
111 \\
83 \\
333 \\
166 \\
83 \\
71 \\
200 \\
71 \\
62 \\
83 \\
333 \\
166 \\
200 \\
20 \\
250 \\
333 \\
20 \\
111 \\
142 \\
83 \\
125\end{array}$ \\
\hline
\end{tabular}


lymphangitis," most of whom showed distinctly elevated levels of antistreptolysin in the blood following attacks of the disease. It seems only reasonable to assume, therefore, that while a secondary streptococcal infection may possibly have initiated the lymphangitis in a few of our cases, the responsible factor in the majority was of a different nature.

Unfortunately, our clinical data were not sufficiently complete so that a truly accurate appraisal of the relationship between the severity of the clinical manifestations and the intensity of the cutaneous responses to filarial antigen could be made. We did note, however, that some of the most marked dermal reactions occurred in patients who had had severe attacks of lymphangitis. In one such individual, following the intradermal injection of $0.1 \mathrm{ml}$. of filarial antigen, a generalized reaction occurred within about 20 minutes. This reaction was characterized by the appearance of a pruritic, urticarial eruption over the chest, back, and abdomen, together with a marked facial edema and some dyspnea.

In several other cases, red streaks were observed to radiate up the arm from the site of antigen injection, followed by transient edema of the neighboring soft parts. These secondary manifestations closely simulated a mild attack of lymphangitis, and it is of interest that they could be provoked by such a small amount of antigen injected to the skin.

The sum of these observations leads us to conclude, as have other investigators, that the recurrent lymphangitis seen in these men can be adequately explained as the result of allergic reactions to the parasitic infection.

\section{SUMMARY}

Antistreptolysin titers were determined in the blood of 45 soldiers suffering from recurrent lymphangitis associated with filariasis contracted in the South Pacific. The titers were within normal limits in 39 of the 45 cases.

The attacks of lymphangitis in these soldiers appeared to be due probably to allergic reactions to the parasitic infection; secondary streptococcal infections were apparently of little or no consequence as an etiological factor.

\section{BIBLIOGRAPHY}

1. Buxton, P. A., Researches in Polynesia and Melanesia. An Account of Investigations in Samoa, Tonga, the Ellice Group, and the New Hebrides in 1924, 1925. London School of Hygiene and Tropical Medicine, London, 1928.

2. Dickson, J. G., Huntington, R. W., Jr., and Eichold, S., Filariasis in defense force, Samoan group. U. S. Nav. M. Bull., 1943, 41, 1240.

3. King, B. G., Early filariasis diagnosis and clinical findings: a report of 268 cases in American troops. Am. J. Trop. Med., 1944, 24, 285.

4. Fogel, R. H., and Huntington, R. W., Jr., Genital manifestations of early filariasis. U. S. Nav. M. Bull., 1944, 43, 263.

5. Flynn, P. D., Filariasis suspects. U. S. Nav. M. Bull., 1944, 42, 1075.

6. Michael, P., Filariasis among Navy and Marine personnel. U. S. Nav. M. Bull., 1944, 42, 1059.

7. Wartman, W. B., Lesions of the lymphatic system in early filariasis. Am. J. Trop. Med., 1944, 24, 299.

8. Culbertson, J. T., Rose, H. M., and Demarest, C. R., Filariasis bancrofti: its diagnosis by immunological tests with antigen derived from Litomosoides carinii. Am. J. Hyg., 1944, 39, 156.

9. Drinker, C. K., and Yoffey, J. M., Lymphatics, Lymph and Lymphoid Tissue. Harvard University Press, Cambridge, 1941.

10. Grace, A. W., Tropical lymphangitis and abscesses. J. A. M. A., 1943, 123, 462.

11. Otero, P. Morales, and Lebron, A. Pomales, Immunological response of cases of recurrent tropical lymphangitis to hemolytic streptococci and their products. Puerto Rico J. Pub. Health and Trop. Med., 1936, 12, 43.

12. Coburn, A. F., and Pauli, R. H., Studies on the immune response of the rheumatic subject and its relationship to activity of the rheumatic process. I. The determination of antistreptolysin titer. J. Exper. Med., 1935, 62, 129.

13. Commission on Acute Respiratory Diseases. Major J. H. Dingle, Director. Endemic exudative pharyngitis and tonsillitis. J. A. M. A., 1944, 125, 1163.

14. Rantz, L. A., Kirby, W. M. M., and Jacobs, A. H., Group A hemolytic streptococcus antibodies: Griffith type agglutinin and antistreptolysin titers in normal men and in acute infections. J. Clin. Invest., 1943, 22, 411 . 